\title{
LAND SURFACE ROUGHNESS PARAMETER RETRIEVAL BY INVERSE SIMULATION OF DUAL-POLARIZATION RADAR BACKSCATTERING
}

Radar remote sensing is a modern and advantageous method for aerospace research of the Earth. The mass commissioning of new high-resolution radar systems based on synthetic aperture radar (SAR) has greatly expanded the capabilities of radar imaging. The expediency of the SAR using was approved in domains that traditionally used remote sensing data, such as cartography, agriculture and forestry, mineral prospecting, environmental security, disaster monitoring, defense.

The primary physical parameter of the land surface, which is registered by non-interferometric SAR, is the radar backscattering coefficient (sigma nought). The received radar signal is a source for the complex simulation of backscattering processes and evaluation of the secondary land surface physical and biophysical characteristics: texture, soil moisture, dielectric permittivity, vegetation cover structure, etc. Herewith the land surface roughness, described by the standard deviation of its vertical irregularities, is one of the most significant entities in any radar simulation. Therefore, the land surface roughness restoration using radar remote sensing data is a high-relevant task. The land surface roughness is an independent physical parameter, in much determining the radar backscattering. However, the roughness correlation length depends on the polarization of the radar signal.

This paper describes a quantitative approach to the land surface roughness recovery by dual-polarization SAR imagery using separate measurements adjustment of independent physical value - dielectric permittivity in different polarizations. The proposed Baghdadi et al. semi-empirical calibration of IEM radar backscattering taking into account the polarization-dependent correlation length is used to ensure the physical equivalence of the land surface dielectric permittivity measurements in different polarizations. In addition, the paper provides the required computational equations, as well as the example of an actual Sentinel-1 radar image processing. The results obtained are generally correspond to the known physical patterns and landscape features of the study area.

Keywords: radar remote sensing, dual-polarization SAR, radar backscattering, polarization ratio, land surface roughness, dielectric permittivity.

С.А. СТАНКЕВИЧ, М.О. СВІДЕНЮК, А.Р. ЛИСЕНКО Науковий центр аерокосмічних досліджень Землі ІГН НАН України

\section{ОЩНКА ПАРАМЕТРІВ ШОРСТКОСТІ ЗЕМНОЇ ПОВЕРХНІ ЗА ДВОХПОЛЯРИЗАЦІЙНИМ РАДІОЛОКАЦІЙНИМ ВІДБИТТЯМ МЕТОДОМ ЗВОРОТНОГО МОДЕЛЮВАННЯ}

\footnotetext{
Радіолокаиійне дистанційне зондування є сучасним та ефективним методом аерокосмічних досліджень Землі. Масове впровадження нових радіолокаційних систем високої розрізненності на основі радіолокаторів з синтезованою апертурою (РСА) значно розширило можливості радарного знімання. Доиільність застосування даного методу було підтверджено в сферах, що традиційно використовують дані дистанційного зондування - картографії, сільському і лісовому господарстві, пошуку корисних копалини, охорони навколищнього середовища, моніторингу надзвичайних ситуацій, обороні.

Основним фізичним параметром земної поверхні, який реєструється неінтерферометричними РСА, $\epsilon$ коефіцієнт зворотного розсіяння (сигма-нуль). Прийнятий радарний сигнал є джерелом для складного моделювання процесів зворотного розсіяння та оцінки вторинних фізичних і біофізичних характеристик земної поверхні -- текстури, зволоженості, діелектричної проникності, структури рослинного покриву тощь. При иьому шорсткість земної поверхні, яка описується середньоквадратичним відхиленням ї̈ вертикальних нерегулярностей, виступає одним з найбільш значущих чинників будь-якого моделювання. Отже, задача відновлення шорсткості земної поверхні за даними радіолокаційного дистанційного зондування є досить актуальною. Шорсткість земної поверхні - ие незалежна фізична величина, що багато в чому визначає радіолокаційне зворотне розсіяння. Проте радіус кореляції шорсткості залежить від поляризації радіолокаиійного сигналу.
} 
У статті описується кількісний підхід до відновлення шорсткості земної поверхні за двохполяризачійними зображеннями РСА на основі узгодження вимірів незалежної фізичної величини діелектричної проникності в різних поляризачіях. Використовується запропонована Багдаді та ін. напівемпіричне калібрування ІЕМ радіолокачійного зворотного розсіяння з урахуванням поляризаційнозалежної величини радіуса корелячії для забезпечення фізичної еквівалентності вимірів діелектричної проникності земної поверхні в різних поляризаціях. Крім того, приведені необхідні розрахункові співвідношення та приклад обробки реального радіолокаџійного зображення Sentinel-1. Одержані результати в иілому відповідають відомим фізичним закономірностям $і$ ландшафтним особливостям території дослідження.

Ключові слова: радіолокачійне дистаниійне зондування, двохполяризаційний РСА, зворотне розсіяння, поляризаційне відночення, иорсткість земної поверхні, діелектрична проникність.

С.А. СТАНКЕВИЧ, М.О. СВИДЕНЮК, А.Р. ЛЬСЕНКО

Научный центр аэрокосмических исследований Земли ИГН НАН Украины

\section{ОЦЕНКА ПАРАМЕТРОВ ШЕРОХОВАТОСТИ ЗЕМНОЙ ПОВЕРХНОСТИ ПО ДВУХПОЛЯРИЗАЦИОННОМУ РАДАРНОМУ ОТРАЖЕНИЮ МЕТОДОМ ОБРАТНОГО МОДЕЛИРОВАНИЯ}

Радиолокационное дистанционное зондирование является современным и эффективным методом аэрокосмических исследований Земли. Массовое появление новых радиолокаиионных систем высокого разрешения на основе радиолокаторов с синтезированной апертурой (РСА) значительно расширило возможности радарной съёмки. Целесообразность применения данного метода была подтверждена в сферах, которые традиционно используют даннье дистанционного зондирования - картографии, сельском и лесном хозяйстве, поиске полезных ископаемых, охраны окружающей среды, мониторинге чрезвычайных ситуации, обороне.

Основным физическим параметром земной поверхности, который регистрируется неинтерферометрическими РСА, является коэффициент обратного рассеяния (сигма-ноль). Принятый радарный сигнал является исходным для сложного моделирования процессов обратного рассеяния и оценки вторичных физических и биофизических характеристик земной поверхности - текстуры, влажности, диэлектрической проницаемости, структуры растительного покрова и т. д. При этом шероховатость земной поверхности, описываемая среднеквадратическим отклонением её вертикальных нерегулярностей, выступпает одним из наиболее значимых факторов любого моделирования. Следовательно, задача восстановления шероховатости земной поверхности по данным радиолокационного зондирования является достаточно актуальной. Шероховатость земной поверхности - это независимая физическая величина, во многом определяющчая радиолокаџионное обратное рассеяние. Однако радиус корреляџии шероховатости зависит от поляризации радиолокационного сигнала.

В статье описывается количественный подход $к$ восстановлению шероховатости земной поверхности по двухполяризационным изображениям РСА на основе согласования измерений независимой физической величинь - диэлектрической проницаемости в разньх поляризациях. Используется предложенная Багдади и др. полуэмпирическая калибровка IЕМ радиолокационного обратного рассеяния с учётом поляризационно-зависимой величины радиуса корреляции для обеспечения физической эквивалентности измерений диэлектрической пронищаемости земной поверхности в разных поляризациях. Кроме того, приведень необходимые расчётные соотночения и пример обработки реального радиолокационного изображения Sentinel-1. Полученные результаты в изелом отвечают известным физическим закономерностям и ландиафтным особенностям территории исследования.

Ключевые слова: радиолокационное дистанциионное зондирование, двухполяризационный РСА, обратное рассеяние, поляризационное отношение, иероховатость земной поверхности, диэлектрическая проницаемость.

\section{Introduction}

The land surface's physical characteristics mapping using the synthetic aperture radar (SAR) backscattering signals is an essential part of radar imagery thematic processing. Thus, a 
significant number of the derivative SAR data products can be produced, such as the spatial distributions of the relative dielectric permittivity, volumetric water content in soils (or soil moisture), vegetation cover fraction, leaf area index, biomass etc.

Currently, numerous heuristic, statistical, semi-empirical and physically conditioned models are developed for producing the derivative SAR-based data products. More or less, all the models are based on the land surface roughness, which wield a major influence on the radar backscattering. However, during the investigation of the land surface parameters by the remote sensing methods, the surface roughness is usually unknown or inaccurate. Therefore, the resulted physical and/or biophysical parameters estimations are under the severe uncertainty.

This paper presents the approach of the land surface roughness recovery based on the Integral Equation Model (IEM) with semi-empirical calibration using the dual-polarization radar backscattering.

\section{State of the art}

The land surface physical and biophysical parameters retrieving from radar data are actively investigated since the SAR appearance. The primary physical parameter acquired by the calibrated SAR is the relative radar backscattering coefficient, or sigma nought $\left(\sigma^{0}\right)$ [1]. The first attempts to simulate radar backscattering are associated with the $\sigma^{0}$ restoration by the radar imaging parameters [2]. Recent studies approve that semi-empirical models, such as the Oh and Dubois models, are suitable for this purpose [3]. Nevertheless, the IEM is recognized as the most relevant physically conditioned model of the radar backscattering [4]. Developed in 1992 [5], this model is repeatedly refined and improved $[6,7]$. Further studies follow two main concepts: 1) the computation of comprehensive SAR-based physical and biophysical land surface parameters, such as soil moisture, LAI etc. [8-10], and 2) backscattering models, mostly semi-empirical, refinement and calibration [11-13].

According to the actual land surface roughness computation by the radar data, there are a wide variety of methods are known, both classical physical simulation [14] and popular modern approaches, for example - the use of fractal geometry [15] or neural networks [16].

The simplified IEM equations for horizontal $(H)$ and vertical $(V)$ radar backscattering have the following form [17]:

$$
\begin{gathered}
\frac{\sqrt{\sigma_{H}^{0}}}{2 k^{2} s \cos ^{2} \theta \sqrt{l e^{-(k l \sin \theta)^{2}}}}=\frac{\varepsilon-1}{\left(\cos \theta+\sqrt{\varepsilon-\sin ^{2} \theta}\right)^{2}} \\
\frac{\sqrt{\sigma_{V}^{0}}}{2 k^{2} s \cos ^{2} \theta \sqrt{l e^{-(k l \sin \theta)^{2}}}}=(\varepsilon-1) \frac{(\varepsilon-1) \sin ^{2} \theta+\varepsilon}{\left(\varepsilon \cos \theta+\sqrt{\varepsilon-\sin ^{2} \theta}\right)^{2}}
\end{gathered}
$$

where $k=\frac{2 \pi}{\lambda}$ is the radar wavenumber, $\lambda$ is the SAR operating wavelength, $\theta$ is the radar beam incident angle, $s$ is the standard deviation of land surface roughness, $l$ is the land surface horizontal profile correlation length [18], $\varepsilon$ is the is the land surface dielectric permittivity. 


\section{Materials and methods}

Since the $\varepsilon$ is an independent physical quantity that characterizes the land surface properties, it should not depend on the way it is observed, in particular, on the SAR polarization. Therefore, the dielectric permittivity estimated by the equations (1) and (2) should be equal or close. In particular, it can be assumed that

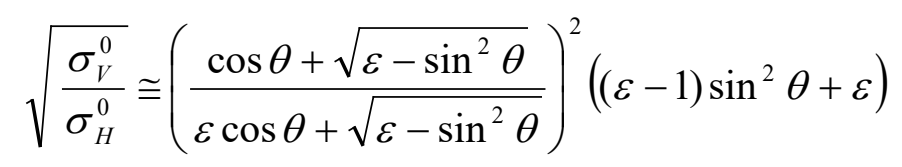

Thus, the $\varepsilon$ can be derived from the equation (3), as shown in the Fig. 1 plot. However, within a defined reasonable range of $\varepsilon=\left[\begin{array}{ll}1 & . .15\end{array}\right]$, the $\sqrt{\frac{\sigma_{V}^{0}}{\sigma_{H}^{0}}}=\left[\begin{array}{ll}1 & . .2 .5\end{array}\right]$, whereas in practice the $\sqrt{\frac{\sigma_{V}^{0}}{\sigma_{H}^{0}}}$ value ranges up to 40

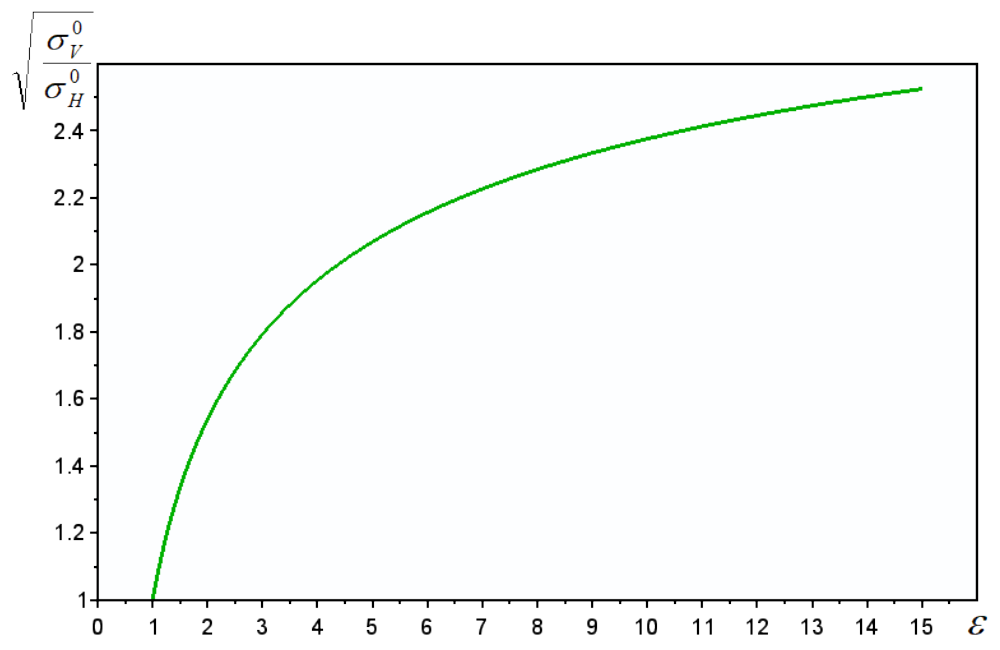

Fig. 1. Graphical representation of the SAR polarizations ratio

In our opinion, the issue is caused by the dependence between the correlation length observed and the radar signal polarization [19]. And no wonder most modern researchers are forced after Baghdadi et al. $[8,11,12]$ to make certain calibrations in the radar backscattering model to obtain practical results [20].

It seems right to introduce an additional multiplier into the ratio (3), depending on the different polarizations correlation length:

Thus, the ratio (3) is refined by the embedding of an additional multiplier, which depends on polarizations correlation length:

$$
\sqrt{\frac{l_{H} e^{-\left(k l_{H} \sin \theta\right)^{2}}}{l_{V} e^{-\left(k l_{V} \sin \theta\right)^{2}}}}=\sqrt{\frac{l_{H}}{l_{V}} e^{(k \sin \theta)^{2}\left(l_{V}^{2}-l_{H}^{2}\right)}}
$$


Usually, correlation lengths $l_{H}, l_{V}$ are expressed through the land surface roughness $s$ by the power-type relationship [19]:

$$
\begin{aligned}
& l_{H}=\alpha_{H} s^{\beta_{H}}=\delta_{H}(\sin \theta)^{\gamma} s^{\eta \theta+\xi_{H}} \\
& l_{V}=\alpha_{V} s^{\beta_{V}}=\delta_{V}(\sin \theta)^{\gamma} s^{\eta \theta+\xi_{V}}
\end{aligned}
$$

where $\alpha, \beta$ are polarization-depended parameters, parameters that can be splitted into polarization-dependent $\delta, \xi$ and polarization-independent $\gamma, \eta$ components. The papers $[21,22]$ provide quantitative values of the IEM parameters, which require the correlation length estimation for the $C$-band SAR.

With the consideration of correlation length, the $\sqrt{\frac{\sigma_{V}^{0}}{\sigma_{H}^{0}}}$ ratio becomes very flexible and expands to almost all observed values, as illustrated by Fig. 2 plots.

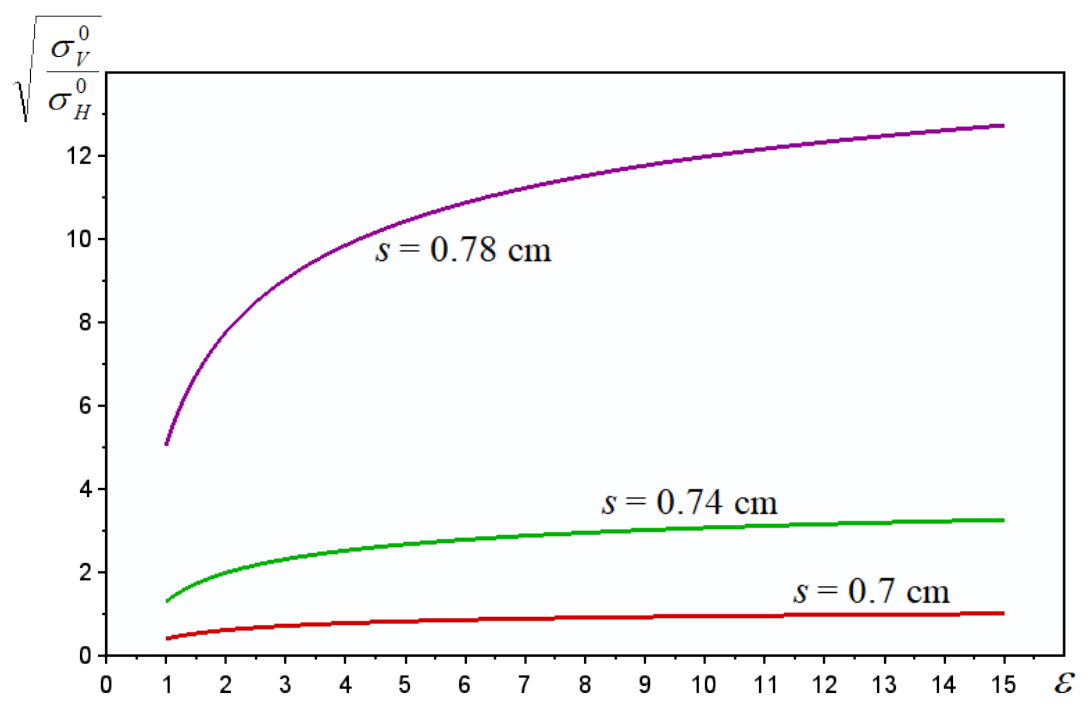

Fig. 2. The SAR polarizations ratio with the land surface roughness

Now, by fitting the optimal value of the land surface roughness standard deviation $s$, it is possible to achieve equality of model polarization ratio with the actual one present in the SAR image. As model benefit, for the already determined $s$ value, a coupled quantity of the land surface dielectric permittivity $\varepsilon$ can be found.

\section{Results and discussion}

The approach described above is implemented as the simulating scripts in the SciLab numerical computation environment and was applied for the Sentinel-1 dual-polarization $C$-band radar image processing (Fig. 3). 


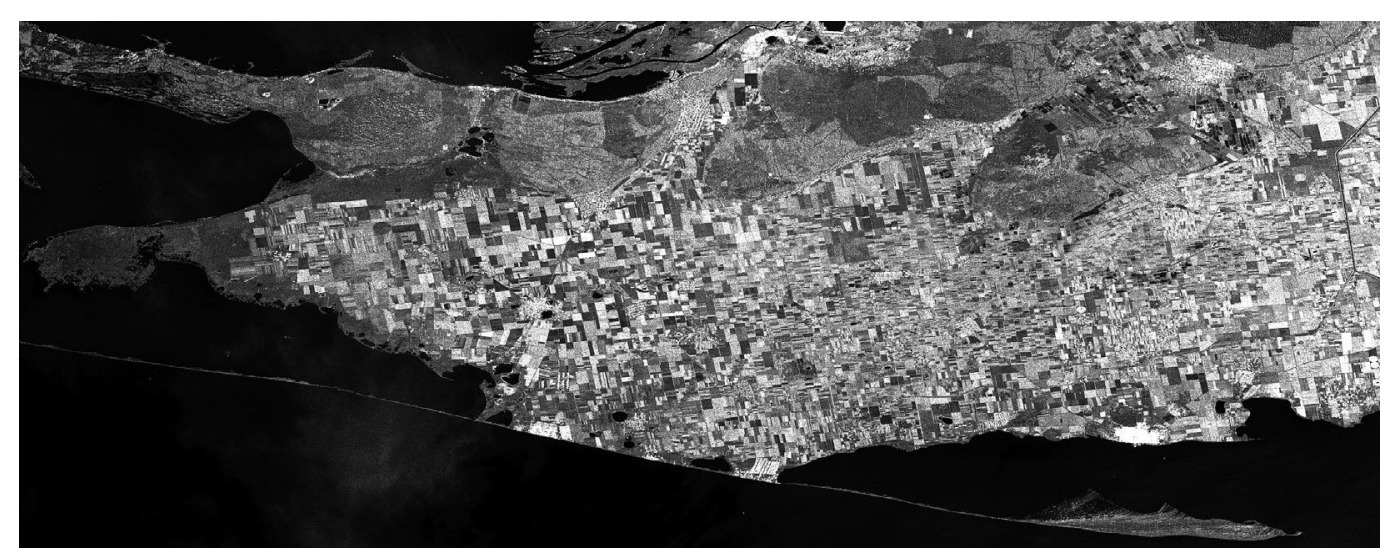

$a$

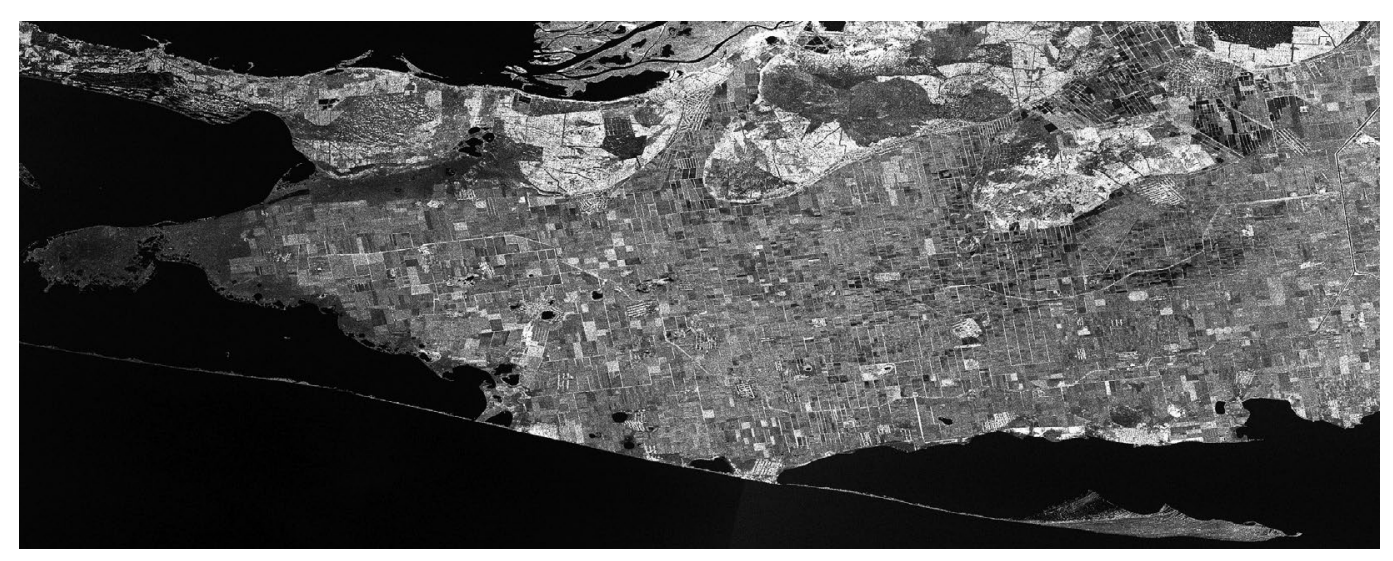

$b$

Fig. 3. Sentinel-1 dual-polarization radar image

Ochakovske - Skadovsk (Ukraine), April 12, 2021, 10 m ground resolution $a-\mathrm{VV}$ polarization band, $b-\mathrm{VH}$ polarization band

The simulation is performed within the range of $s=[0.4 . .1 .7] \mathrm{cm}$, resulting in a pixel map of the land surface roughness distribution. Grey shades on the Fig. 3 represent areas with the different level of the radar backscattering at the curtain land cover: light shades correspond to rough surfaces (vegetated areas, arable fields etc.); and dark shades correspond to flat surfaces (water, paved roads etc.).

Next, a joint map of the land surface dielectric permittivity is shown in Fig. 4, was produced using pre-estimated roughness values. This map can be useful for obtaining the SARbased physical and biophysical parameters providing the context information for study areas thematic analyses. 


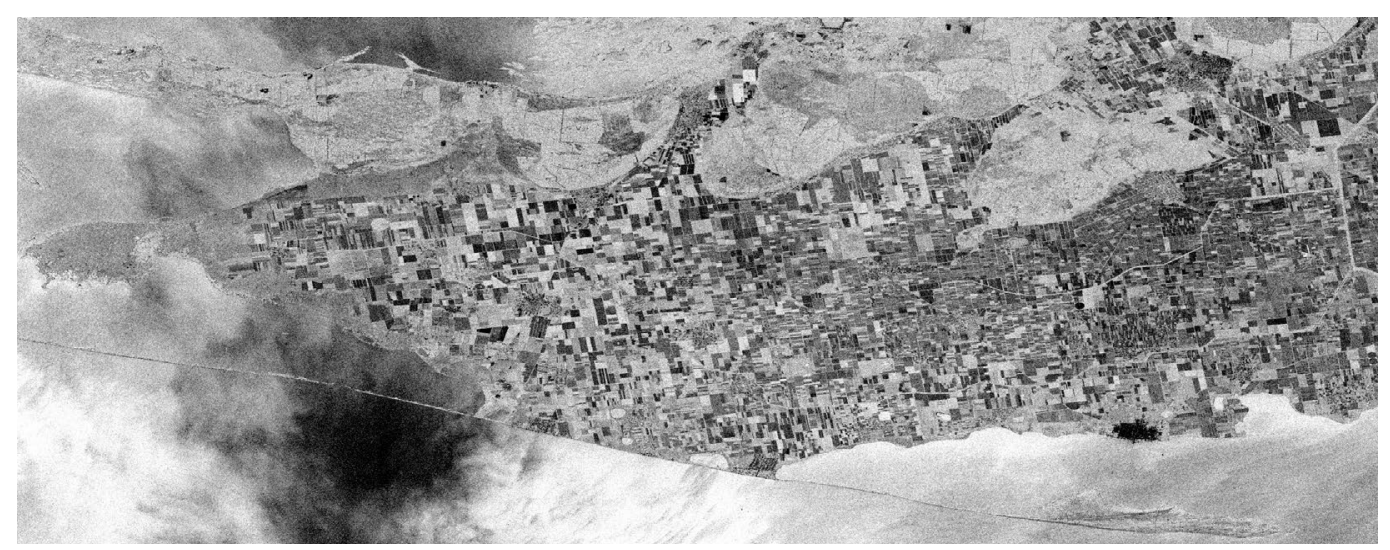

Fig. 4. The SAR-based land surface dielectric permittivity map

The Fig. 4 represents in grey shades the areas with different values of the $\varepsilon$ : light tones correspond to strongly electrically polarized materials and substances (water, dry soil, vegetation, polymers); dark tones correspond to surfaces, where radar signals penetration depth is low (dry rocks, dry soil, construction materials etc.). The statistics of dielectric permittivity distribution within the map Fig. 4 looks somewhat underestimated, but in large one meets the known general physical properties of the land surface.

\section{Conclusions}

In this study, we attempted to provide a comprehensive solution for the dielectric permittivity estimation based on the semi-empirical radar backscattering model. For this purpose, the effective correlation length is introduced into the integral equation model (IEM) as a calibrating parameter. The implementation of this parameter ensures the mutual adjustment of independent physical characteristics of the land surface, namely roughness and dielectric permittivity. The coupled processing of the Sentinel-1 dual-polarization radar imagery increases the physical conditioning of the model and the propriety of the quantitative estimates received.

The described approach is appropriate for dual-polarization radar data. Application of the presented approach for multi-polarized SAR data can be performed is possible is possible by providing extra degrees of freedom. As a result, the scope of this approach applicability will expand.

Future investigations will be devoted to experiments with modern backscattering models, radar imagery and field data. The experiments will be focused on the fitting, calibrating and refining used radar backscattering models over the various land cover types. After large-scale tryout and elaboration, it will be possible to recommend the developed approach for the practical applications of radar remote sensing.

\section{References}

1. Jansing E.D. Introduction to Synthetic Aperture Radar: Concepts and Practice. New York: McGraw-Hill, 2021, 208 p. ISBN: 9781260458961

2. Goswami B., Kalita M. Radar backscattering measurement of bare soil and vegetation covered soil using X-band and full polarization. The International Archives of the Photogrammetry, Remote Sensing and Spatial Information Sciences, 2014, vol. XL, no. 8, pp. 733-736. DOI: 10.5194/isprsarchives-XL-8-733-2014 
3. Fieuzal R., Baup F. Improvement of bare soil semi-empirical radar backscattering models (Oh and Dubois) with SAR multi-spectral satellite data ( $X$-, $C$ - and $L$-bands). Advances in Remote Sensing, 2016, vol. 5, no. 4, pp. 296-314. DOI: 10.4236/ars.2016.54023

4. Fung A.K. Microwave Scattering and Emission Models and their Applications. Norwood: Artech House, 1994, 592 p. ISBN: 9780890065235

5. Fung A.K., Li Z., Chen K.S. Backscattering from a randomly rough dielectric surface. IEEE Transactions on Geoscience and Remote Sensing, 1992, vol. 30, no. 2, pp. 356-369. DOI: 10.1109/36.134085

6. Fung A.K., Chen K.S. An update on the IEM surface backscattering model. IEEE Geoscience and Remote Sensing Letters, 2004, vol. 1, no. 2, pp. 75-77, DOI: 10.1109/LGRS.2004.826564

7. Chen K.-L., Chen K.-S., Li Z.-L., Liu Y. Extension and validation of an Advanced Integral Equation Model for bistatic scattering from rough surfaces. Progress in Electromagnetics Research, 2015, Vol. 152, pp. 59-76. DOI: 10.2528/PIER15011409

8. Baghdadi N., Holah N., Zribi M. Soil moisture estimation using multi-incidence and multipolarization ASAR data. International Journal of Remote Sensing, 2006, vol. 27, no. 10, pp. 1907-1920. DOI: 10.1080/01431160500239032

9. Sayyad S.B., Shaikh M.A., Kolhe S.B., Khirade P.W. Geophysical parameter retrieval for microwave $\mathrm{C}$ band synthetic aperture radar (SAR) dataset using integral equation model. The International Archives of the Photogrammetry, Remote Sensing and Spatial Information Sciences, 2018, vol. XLII, no. 5, pp. 689-692. DOI: 10.5194/isprs-archives-XLII-5-689-2018

10. Tao L., Wang G., Chen X., Li J., Cai Q. Estimation of soil moisture using a vegetation scattering model in wheat fields. Journal of Applied Remote Sensing, 2019, vol. 13, no. 4, A. 044503, 16 p. DOI: 10.1117/1.JRS.13.4.044503

11. Baghdadi N., Holah N., Zribi M. Calibration of the Integral Equation Model for SAR data in $C$-band and $\mathrm{HH}$ and VV polarizations. International Journal of Remote Sensing, 2006, vol. 27, no. 4, pp. 805-816. DOI: 10.1080/01431160500212278

12. Baghdadi N., Chayya J.A., Zribi M. Semi-empirical calibration of the Integral Equation Model for SAR data in C-band and cross polarization using radar images and fi eld measurements. IEEE Geoscience and Remote Sensing Letters, 2011, vol. 8, no. 1, pp. 14-18. DOI: $10.1109 /$ LGRS.2010.2050054

13. Panciera R., Tanase M.A., Lowell K., Walker J.P. Evaluation of IEM, Dubois, and Oh radar backscatter models using airborne $L$-band SAR. IEEE Transactions on Geoscience and Remote Sensing, 2014, vol. 52, no. 8, pp. 4966-4979. DOI: 10.1109/ TGRS.2013.2286203

14. Sun L., Dabboor M., Belair S., Carrera M.L., Merzouki A. Simulating C-band SAR footprint-scale backscatter over agricultural area with a physical land surface model. Water Resources Research, 2019, vol. 55, no. 6, pp. 4594-4612. DOI: 10.1029/2019WR025163

15. Ghafouri A., Amini J., Dehmollaian M., Kavoosi M.A. Measuring the surface roughness of geological rock surfaces in SAR data using fractal geometry. Comptes Rendus Geoscience, 2017, vol. 349, no. 3, pp. 114-125. DOI: 10.1016/j.crte.2017.04.003

16. Mirsoleimani H.R., Sahebi M.R., Baghdadi N., El Hajj M. Bare soil surface moisture retrieval from Sentinel-1 SAR data based on the calibrated IEM and Dubois models using neural networks. Sensors, 2019, vol. 19, no. 14, A. 3209, 12 p. DOI: 10.3390/s19143209

17. Stankevich S.A., Piestova I.O., Shklyar S.V., Lysenko A.R. Satellite dual-polarization radar imagery superresolution under physical constraints. In: Shakhovska N., Medykovskyy M.O. (Eds). Advances in Intelligent Systems and Computing. Cham: Springer Nature, 2020, pp. 439-452. DOI: 10.1007/978-3-030-33695-0_30 
18. Verhoest N.E.C., Lievens H., Wagner W., Álvarez-Mozos J., Moran M.S., Mattia F. On the soil roughness parameterization problem in soil moisture retrieval of bare surfaces from synthetic aperture radar. Sensors, 2008, vol. 8, no. 7, pp. 4213-4248. DOI: 10.3390/s8074213

19. Álvarez-Mozos J., González-Audícana M., Casalí J., Larrañaga A. Effective versus measured correlation length for radar-based surface soil moisture retrieval. International Journal of Remote Sensing, 2008, vol. 29, no. 17-18, pp. 5397-5408.- DOI: 10.1080/ 01431160802036367

20. Ranjbar S., Zarei A., Hasanlou M., Akhoondzadeh M., Amini J., Amani M. Machine learning inversion approach for soil parameters estimation over vegetated agricultural areas using a combination of water cloud model and calibrated integral equation model. Journal of Applied Remote Sensing, 2021, vol. 15, no. 1, A. 018503, 17 p. DOI: 10.1117/ 1.JRS.15.018503

21. Ezzahar J., Ouaadi N., Zribi M., Elfarkh J., Aouade G., Khabba S., Er-Raki S., Chehbouni A., Jarlan L. Evaluation of backscattering models and support vector machine for the retrieval of bare soil moisture from Sentinel-1 data. Remote Sensing, 2020, vol. 12, no. 1, A. 72, 20 p. DOI: 10.3390/rs12010072

22. Zhang L., Li H., Xue Z. Calibrated integral equation model for bare soil moisture retrieval of synthetic aperture radar: A case study in Linze County. Applied Sciences, 2020, vol. 10, no. 21, A. 7921, 17 p. DOI: 10.3390/app10217921

Станкевич Сергій Арсенійович - доктор технічних наук, професор, головний науковий співробітник Наукового центру аерокосмічних досліджень Землі IГН НАН України, e-mail: st@casre.kiev.ua, ORCID: 0000-0002-0889-5764

Свіденюк Михайло Олегович - аспірант Наукового центру аерокосмічних досліджень Землі IГН НАН України, e-mail: svideniuk_m@ukr.net, ORCID: 0000-0003-21673522

Лисенко Артур Ростиславович - аспірант Наукового центру аерокосмічних досліджень Землі ІГН НАН України, е-mail: mercennarius94@gmail.com, ORCID: 00000003-2923-8648 